\author{
TOMASZ BIELIŃSKI* \\ MAŁGORZATA LEWIŃSKA
}

\title{
POSTRZEGANIE ZATRUDNIENIA OSÓB NIEPEŁNOSPRAWNYCH W CHINACH I STANACH ZJEDNOCZONYCH
}

Jedną z najważniejszych kwestii dotyczących roli osób niepełnosprawnych w gospodarce jest sposób postrzegania ich w społeczeństwie. W niniejszym opracowaniu porównano, jak postrzega się zatrudnianie osób niepełnosprawnych w Chinach i Stanach Zjednoczonych. Porównanie to opiera się na badaniu ankietowym przeprowadzonym wśród społeczności chińskiej w okresie luty-marzec 2020 r., obejmującym grupę 121 osób. Badanie zrealizowano za pomocą metody CAWI (ang. Computer Assisted Web Interview), a jego wyniki zestawiono z wynikami badania amerykańskiego autorstwa Gary'ego N. Sipersteina, Neila Romana, Amandy Mohler i Robina Parkera, dzięki czemu możliwe było wskazanie różnic w postrzeganiu pracy osób niepełnosprawnych, roli, jaką odgrywają w firmach, oraz efektywności i zadowolenia $\mathrm{z}$ ich pracy.

Postęp naukowo-techniczny stworzył większe możliwości zapewnienia pomocy niepełnosprawnym, ale jednocześnie wzrosła liczba potrzebujących. Osoby niepełnosprawne rzadziej izolują się od społeczeństwa, chcą bowiem realizować się w życiu zawodowym i publicznym, dlatego też kontakt z nimi, pośredni lub bezpośredni, jest częstszy ${ }^{1}$. Pełnią one również odpowiedzialne funkcje publiczne, np. poselskie, naukowe, i podejmują działalność charytatywna. Narastające zainteresowanie niepełnosprawnością wynika z coraz częstszego występowania zjawiska niepełnosprawności, na które z kolei ma wpływ rozwój medycyny, zmniejszający śmiertelność w wielu urazach i chorobach, oraz duża liczba konfliktów zbrojnych ${ }^{2}$. Ponadto regulacje prawne wspierające osoby niepełnosprawne, poświęcone tej tematyce kampanie społeczne i większa kultura pedagogiczno-psychologiczna

* ORCID: 0000-0001-5290-3787, DOI: 10.4467/23538724GS.21.002.14834

1 M. Hebl, R. Kleck, Spoteczne konsekwencje niepetnosprawności fizycznej [w:] Spoteczna psychologia piętna, red. T. Heatherton, R. Kleck, M. Hebl, J.G. Hull, tłum. J. Radzicki i in., Warszawa 2008, s. 384-402.

2 C. Barnes, G. Mercer, Niepetnosprawność, tłum. P. Morawski, Warszawa 2008, s. 43. 
sprzyjaja zmniejszeniu dystansu społecznego między jednostkami niepełnosprawnymi a osobami zdrowymi ${ }^{3}$.

Niestety w wielu krajach stale pogłębia się dysproporcja między poziomem życia osób niepełnosprawnych a innych osób. Ubóstwo pozostaje kluczowa przeszkoda w rozwoju osób niepełnosprawnych ${ }^{4}$. Często borykają się oni z problemem znalezienia pracy. Niesłusznie przypisuje się im wiele ograniczeń, bez wcześniejszego zweryfikowania ich kwalifikacji. Stereotypizacja niepełnosprawności jest zjawiskiem wielce niesprawiedliwym, ale tak powszechnym, że wpływa na jakość życia większości niepełnosprawnych. Zauważono jednak, że wiedza pracodawców w zakresie zatrudniania osób z niepełnosprawnościami może wpłynąć na korzystniejsze podejście do tej grupy osób $b^{5}$. Przykładowo wyniki badania stosunku pracodawców do zatrudniania niesłyszących wskazywały, że pracodawcy mający już doświadczenie $\mathrm{w}$ pracy z nimi byli bardziej pozytywnie nastawieni do ponownego zatrudnienia takiej osoby ${ }^{6}$.

Celem niniejszego artykułu jest porównanie postaw społeczeństwa wobec kwestii zatrudniania osób niepełnosprawnych w Chinach i Stanach Zjednoczonych, z uwzględnieniem panujących w obu krajach zasad zatrudnienia i regulacji prawnych oraz podejmowanych w tej kwestii inicjatyw. W związku z tym przyjęto następujące hipotezy:

H1. Zarówno Chińczycy, jak i Amerykanie pozytywnie oceniają zatrudnianie osób niepełnosprawnych na tle innych działań społecznych.

H2. Mieszkańcy obydwu krajów korzystnie postrzegają funkcjonowanie osób niepełnosprawnych w firmie.

H3. Osoby mające doświadczenie z niepełnosprawnymi są przychylniej do nich nastawione.

\section{Istota niepełnosprawności z punktu widzenia chińskiego i amerykańskiego ustawodawstwa}

Niepełnosprawność oznacza czasowy lub trwały spadek sprawności fizycznej lub psychicznej o zróżnicowanej etiologii - od wad wrodzonych po wady nabyte w toku

3 J. Wolińska, Percepcja społeczna, stereotyp niepetnosprawności-perspektywa ak.tora i obserwatora, „Annales Universitatis Mariae Curie-Skłodowska. Sectio J, Paedagogia-Psychologia" 2015, vol. 28.

4 Disability: IN. Global Directory, China, 2019, https://private.disabilityin.org/global/china/ (dostęp: 3.07.2021).

5 B. Hernandez, C. Keys, F. Balcazar, Employer attitudes toward workers with disabilities and their ADA employment rights: A literature review, „Journal of Rehabilitation” 2000, vol. 66, s. 4-16.

6 D.D. Unger, Employers' attitudes toward persons with disabilities in the workforce: myths or realities?, „Focus on Autism and Other Developmental Disabilities” 2002, vol. 17, issue 1. 
życia jednostki wskutek chorób czy nieszczęśliwych wypadków ${ }^{7}$. Światowa Organizacja Zdrowia uznaje za niepełnosprawne osoby o naruszonej sprawności psychofizycznej, powodującej ograniczenie sprawności i aktywności życiowej w stopniu utrudniającym odgrywanie właściwych dla nich ról społecznych ${ }^{8}$. Osoby z niepełnosprawnościami zazwyczaj stanowią największą grupę wśród mniejszości danego narodu. Z reguły też jakość ich życia jest zasadniczo niższa od jakości życia pozostałych członków społeczeństwa i są bardziej zagrożone bezrobociem². Postrzeganie niepełnosprawnych zmienia się jednak z czasem ${ }^{10}$.

Osoby z niepełnosprawnością przyznaja, że ich organizmy nie funkcjonują w pełni tak jak powinny, jednak nazywają ten fakt upośledzeniem. Zaznaczają, że to nie upośledzenie czyni ich niepełnosprawnymi, lecz społeczeństwo ${ }^{11}$. Potwierdza to Fred Davies, który wskazuje, że funkcjonowanie osób niepełnosprawnych w życiu społecznym zależy w znacznej mierze od charakteru ich relacji z osobami zdrowymi ${ }^{12}$.

Ustawa Chińskiej Republiki Ludowej o ochronie osób niepełnosprawnych (1990) w art. 2 stanowi, że ,niepełnosprawny oznacza osobę, która cierpi na zaburzenia lub utratę określonego narządu lub funkcji, psychologicznie, fizjologicznie lub w strukturze anatomicznej, i która utraciła całkowicie lub częściowo zdolność do funkcjonowania w sposób normalny"13. Definicja ta obejmuje osoby z „niepełnosprawnością wzrokową, słuchową, fizyczną lub niepełnosprawnością mowy, upośledzeniem umysłowym, zaburzeniem psychicznym, oraz wieloma niepełnosprawnościami występującymi jednocześnie”. Natomiast zgodnie z ustawą o niepełnosprawności Amerykanów (ang. Americans with Disabilities Act of 1990, ADA) uważa się, że dana osoba jest niepełnosprawna, jeśli jest „upośledzona fizycznie lub psychicznie, co ma znaczny i niekorzystny wpływ na jej zdolność do wykonywania codziennych czynności”. Dokument ten wskazuje również, że dyskryminowanie osoby na podstawie jej związku z osobą niepełnosprawną jest niezgodne z prawem ${ }^{14}$.

7 J. Wolińska, Percepcja spoteczna..., s. 46.

8 A. Wilmowska-Pietruszyńska, Niepetnosprawność, „Orzecznictwo Lekarskie” 2009, nr 6(2), s. 83-89.

9 R. Ledman, D. Brown, The American with Disabilities Act: The Cutting Edge to Managing Disability, „Sam Advanced Management Journal” 1993, vol. 58, s. 17-20.

10 P. Mergenhagen, Enabling Disabled Workers, „American Demographics” 1997, vol. 19, no. 7, s. $36-42$.

11 Greater Manchester Coalition of Disabled People, Young Disabled People's Group, 1996, Resource Sheet I, s. 13.

12 F. Davis, Deviance disavowal: The management of strained interaction the visibly handicapped, „Social Problems" 1961, vol. 9, no. 2, s. 120-132.

13 Law of the People's Republic of China on Protection of Disabled Persons.

14 Ada National Network, What is the definition of disability under the ADA?, 2019, https://adata. $\mathrm{org} /$ faq/what-definition-disability-under-ada (dostęp: 3.07.2021). 


\section{Prawa dotyczące osób niepełnosprawnych w Chinach i Stanach Zjednoczonych}

Chińska ustawa o ochronie osób niepełnosprawnych odnosi się do ich praw w zakresie możliwości zatrudnienia, dostępu do edukacji, odpowiedzialności prawnej i wystarczającej opieki. Dyskryminacja czy znieważanie osób ze względu na niepełnosprawność są zabronione ${ }^{15}$. Ponadto Konstytucja Chińskiej Republiki Ludowej w art. 45 wskazuje, że „Obywatele Chińskiej Republiki Ludowej mają prawo do pomocy materialnej ze strony państwa i społeczeństwa, gdy są starzy, chorzy lub niepełnosprawni. Państwo rozwija ubezpieczenia społeczne, ulgi socjalne, usługi medyczne i zdrowotne, które są niezbędne, aby umożliwić obywatelom korzystanie z tych praw. (...) Państwo i społeczeństwo pomagają w zdobyciu pracy, środków utrzymania i wykształcenia niewidomym, głuchoniemym i pozostałym niepełnosprawnym obywatelom"16. W 1994 r. wydano rozporządzenie w sprawie edukacji osób niepełnosprawnych, które miało na celu promowanie dostępu niepełnosprawnych do edukacji, chociaż jak podaje Human Rights Watch, ,nie poczyniło ono odpowiednich postępów w zakresie włączania dzieci niepełnosprawnych do zwykłych szkół zgodnie z wymogami prawa międzynarodowego"17. W 2007 r. w Chinach podpisano Konwencję Narodów Zjednoczonych o prawach osób niepełnosprawnych, która umacnia ich prawo do edukacji ${ }^{18}$. W myśl ustawy o ochronie osób niepełnosprawnych z 1990 r. rodziny i społeczność ponoszą odpowiedzialność za opiekę nad niepełnosprawnymi ${ }^{19}$. W rezultacie oficjalnego seminarium poświęconego problematyce zdrowia psychicznego, które w 1999 r. Światowa Organizacja Zdrowia zorganizowała dla rządu chińskiego, rząd ów zobowiązał się do „poprawy wsparcia osób niepełnosprawnych w zakresie opieki zdrowia psychicznego, wzmocnienia współpracy międzysektorowej, ustanowienia strategii i planu działania dotyczacych zdrowia psychicznego i ochrony praw pacjentów"20.

15 中国残疾人联合会 [Zhōngguó cánjí rén liánhé hui]. Regulations on the Employment of Persons with Disabilities, http://www.cdpf.org.cn/english/Resources/lawsregulations/201603/ t20160303_542878.shtml (dostęp: 3.03.2020).

${ }^{16}$ Konstytucja Chińskiej Republiki Ludowej, przekład z jęz. chińskiego W. Lan, M. Dargas, Gdańsk 2012.

17 China: End Discrimination, Exclusion of Children With Disabilities, Human Rights Watch, 2013, https://www.hrw.org/news/2013/07/15/china-end-discrimination-exclusion-children-disabilities (dostęp: 3.07.2021).

18 V. Hernandez, Making Good on the Promise of International Law: The Convention on the Rights of Persons with Disabilities and Inclusive Education in China and India, „Pacific Rim Law \& Policy Journal Association" 2008, vol. 17, s. 497.

19 J. Kritzer, Special Education in China, „Eastern Education Journal” 2011, vol. 40, no. 1, s. 57-63.

$20 \mathrm{~J}$. Liu, H. Ma, Mental health system in China: history, recent service reform and future challenges, „World Psychiatry" 2011, vol. 10, no. 3, s. 210-216. 
Ważną organizacją dla $83 \mathrm{mln}$ osób z różnymi kategoriami niepełnosprawności w Chinach jest utworzona w 1988 r. Chińska Federacja Osób Niepełnosprawnych (ang. China Disabled Persons Federation, CDPF). Jej misja obejmuje promowanie rozwoju osób niepełnosprawnych, utrzymanie ich równego i pełnego uczestnictwa w życiu społecznym oraz umożliwienie im udziału w osiagnięciach społecznych, materialnych i kulturowych ${ }^{21}$.

W Stanach Zjednoczonych niepełnosprawność jest klasyfikowana według rodzajów upośledzeń. Wyróżnia się upośledzenia fizyczne lub psychiczne, uwzględnia się przy tym umiejętności decyzyjne i pamięci, zdolności widzenia, określa, czy są one wystarczające, i wreszcie, czy niepełnosprawny zależy od innej osoby, która pomaga w wykonywaniu zadań. Według spisu powszechnego: „Około 1 na 5 Amerykanów cierpi z powodu pewnego rodzaju niepełnosprawności, a 1 na 10 cierpi na poważną niepełnosprawność”22.

Osoby niepełnosprawne są chronione na podstawie trzech praw określonych w ustawie o niepełnosprawności (The Americans with Disabilities Act) i ustawie o edukacji osób niepełnosprawnych (Individuals with Disabilities Education Act) oraz w sekcji 504 ustawy o rehabilitacji (Section 504 of the Rehabilitation Act) ${ }^{23}$.

The US Social Security Administration (SSA) definiuje niepełnosprawność w kategoriach niezdolności jednostki do wykonywania działalności zarobkowej (ang. substantial gainful activity, SGA), przez co rozumie się pracę o płacy minimalnej lub wyższej. Agencja łączy SGA z listą schorzeń kwalifikujących do świadczeń z tytułu niepełnosprawności. Osobom niepełnosprawnym przysługuje wypłata, co gwarantuje, że zawsze będą otrzymywać wynagrodzenie, gdy muszą wziąć urlop lub nie mogą pracować z powodu choroby ${ }^{24}$.

\section{Zasady i zachęty dotyczące zatrudniania osób niepełnosprawnych w Chinach}

Artykuł 42 Konstytucji Chińskiej Republiki Ludowej stanowi, że: „Praca jest kwestią honoru dla każdego obywatela Chińskiej Republiki Ludowej, który jest w stanie pracować. Państwo zachęca obywateli do podjęcia aktywnego i twórczego udziału w pracy". Państwo chińskie w myśl art. 36 ustawy ChRL o ochronie osób

21 中国政府主要职能 [Main Functions of the China Disabled Persons' Federation, China Disabled Persons' Federation], http://www.cdpf.org.cn/english/About/overview_1793/ (dostęp: 3.07.2021).

22 US Census Bureau, Census Brief. Disabilities Affect One-Fifth of All Americans, Washington, DC, December 1997, CENBR/97-5.

23 C. Siordia, Proxy-reports in the Ascertainment of Disability Prevalence with American Community Survey Data, „Journal Frailty \& Aging” 2014, vol. 3, no. 4, s. 238-246.

24 Social Security Administration, Disability Benefits, No. 05-10029, [b.m.] 2021, s. 1-20. 
niepełnosprawnych stosuje preferencyjne podatki w odniesieniu do: przedsiębiorstw i pracodawców, którzy spełnili lub przekroczyli swój kontyngent (1,5\% zatrudnionych osób niepełnosprawnych), zakładów opieki społecznej i instytucji dla osób niepełnosprawnych oraz samozatrudnionych osób niepełnosprawnych. Jednocześnie państwo ma zapewniać pomoc takim firmom w zakresie produkcji, zarządzania, technologii, kapitału, materiałów, miejsca pracy itp., a także zwalniać z opłat administracyjnych samozatrudniające się osoby niepełnosprawne ${ }^{25}$. Ponadto publiczne instytucje zapewniaja bezpłatne usługi w zakresie zatrudnienia niepełnosprawnych. Instytucje służb zatrudnienia utworzone przez federacje osób niepełnosprawnych pomagaja niepełnosprawnym i potencjalnym pracodawcom, organizując bezpłatne poradnictwo zawodowe, przysposobienie do pracy i szkolenia ${ }^{26}$.

Rząd chiński ustanowił system kwot, zgodnie z którym wszyscy pracodawcy publiczni i prywatni mają obowiązek zarezerwowania nie mniej niż 1,5\% ofert pracy dla niepełnosprawnych. Organizacje niespełniające tego wymogu muszą uiścić opłatę na rzecz Funduszu Bezpieczeństwa Zatrudnienia Osób Niepełnosprawnych, który z kolei wspiera szkolenia zawodowe i usługi pośrednictwa pracy dla niepełnosprawnych. W proces monitorowania zaangażowane są organy podatkowe i organizacje działające na rzecz osób niepełnosprawnych. Poprzez inicjatywy, takie jak zachęty podatkowe oraz udzielanie pomocy finansowej, technicznej i innej, rząd wspiera przedsiębiorstwa opieki społecznej rekrutujące niepełnosprawnych pracowników i zachęca osoby niepełnosprawne do podejmowania samozatrudnienia ${ }^{27}$.

Istnieją specjalne zasady dotyczące zatrudniania pracowników niepełnosprawnych w Chinach, na podstawie których dla pracodawców przewidziane są głównie ulgi podatkowe lub zwolnienia z podatków (tab. 1). O możliwości skorzystania z tych udogodnień decyduje wiele czynników, przy czym często zależy to od wielkości i lokalizacji firmy.

25 China Disabled Person's Federation, Law on the Protection of Persons with Disabilities, http:// www.cdpf.org.cn/english/Resources/lawsregulations/201603/t20160303_542879.shtml (dostęp: 3.05.2020).

26 Ibidem.

27 Facts on People with Disabilities in China. International Labour Organization, s. 1-2 https://www. ilo.org/wcmsp5/groups/public/---asia/---ro-bangkok/---ilobeijing/documents/publication/ wcms_142315.pdf (dostęp: 14.09.2020). 
Tabela 1. Chiny - ulgi podatkowe dla osób zatrudniających niepełnosprawnych pracowników

\begin{tabular}{|l|l|l|l|}
\hline Rodzaj podatku & \multicolumn{1}{|c|}{ Świadczenie } & \multicolumn{1}{|c|}{ Zasady } & \multicolumn{1}{c|}{ Zasięg } \\
\hline $\begin{array}{l}\text { Podatek } \\
\text { dochodowy od } \\
\text { osób prawnych } \\
\text { (CIT) }\end{array}$ & $\begin{array}{l}\text { Zwolnienie } \\
\text { z podatku }\end{array}$ & $\begin{array}{l}\text { Pracodawcy wypłacający } \\
\text { wynagrodzenia pracownikom } \\
\text { niepełnosprawnym są } \\
\text { uprawnieni do odliczenia CIT } \\
\text { w wysokości 200\% }\end{array}$ & Krajowy \\
\hline $\begin{array}{l}\text { Indywidualny } \\
\text { podatek } \\
\text { dochodowy (IIT) }\end{array}$ & $\begin{array}{l}\text { Odliczenie } \\
\text { podatku }\end{array}$ & $\begin{array}{l}\text { Podatek dochodowy pobierany } \\
\text { od wynagrodzenia pracownika } \\
\text { niepełnosprawnego może } \\
\text { zostać obniżony }\end{array}$ & $\begin{array}{l}\text { Krajowy, ale kwota } \\
\text { odliczenia różni } \\
\text { się zależności } \\
\text { od regionu }\end{array}$ \\
\hline VAT & $\begin{array}{l}\text { Zwolnienie } \\
\text { z podatku }\end{array}$ & $\begin{array}{l}\text { Usługi podlegające } \\
\text { opodatkowaniu świadczone } \\
\text { przez osoby niepełnosprawne } \\
\text { sa zwolnione z podatku VAT, } \\
\text { ale z limitem 35 000 RMB } \\
\text { rocznie }\end{array}$ & Krajowy \\
\hline
\end{tabular}

Źródło: D. Shira \& Associates, Hiring Disabled Workers in China: Incentives and Challenges, 2016, https:// www.chinabusinessreview.com/hiring-disabled-workers-in-china-incentives-and-challenges/ (dostęp: 3.07.2021).

1. Podatek dochodowy od osób prawnych (CIT)

W Chinach firmy mogą odliczyć roczne wynagrodzenie pracownika pełnosprawnego od zysków opodatkowanych przez CIT. W odniesieniu do pracowników niepełnosprawnych firmy mogą odliczyć podwójną pensję. Przykładowo, jeśli roczne wynagrodzenie pracownika niepełnosprawnego wynosi 100 tys. RMB, firma będzie mogła odliczyć 200 tys. RMB od podstawy opodatkowania CIT.

Aby kwalifikować się do tej korzyści, chińskie firmy muszą spełniać wszystkie następujące wymagania: pracownik niepełnosprawny musi mieć co najmniej roczna umowę o pracę lub umowę o świadczenie usług z firma; firma musi płacić miesięczne koszty zabezpieczenia społecznego niepełnosprawnemu pracownikowi; wynagrodzenie pracownika niepełnosprawnego nie może być niższe niż najniższe wynagrodzenie wypłacone pracownikowi pełnosprawnemu.

2. Indywidualny podatek dochodowy (IIT)

Każda osoba niepełnosprawna zatrudniona w Chinach kwalifikuje się do odliczenia IIT. Kwota odliczenia różni się jednak w zależności od regionu, a obszary zamożniejsze zwykle zapewniają większe odliczenia. W tabeli 2 przedstawiono przykład takiej sytuacji w prowincji Guangdong, która jest jedną z najbogatszych w Chinach. 
Tabela 2. Odliczenie indywidualnego podatku dochodowego dla pracowników niepełnosprawnych w Guangzhou

\begin{tabular}{|l|c|}
\hline \multicolumn{1}{|c|}{ Roczna pensja (RMB) } & Odliczenie (\%) \\
\hline Poniżej 60000 & 50 \\
\hline $60000-100000$ & 40 \\
\hline $100000-150000$ & 30 \\
\hline $150000-200000$ & 20 \\
\hline Więcej niż 200 000 & 10 \\
\hline
\end{tabular}

Źródło: D. Shira \& Associates, Hiring Disabled Workers...

\section{Podatek VAT}

Wymagania dotyczące zakwalifikowania do zwolnienia z podatku VAT w Chinach sa rozbudowane. Co najmniej 25\% zatrudnionych w firmie muszą stanowić osoby niepełnosprawne, a firma musi zatrudniać co najmniej 10 niepełnosprawnych pracowników. W praktyce znaczy to, że zwolnienie z podatku VAT jest dostępne tylko dla większych przedsiębiorstw. Na przykład gdyby startup zatrudniał 16 pracowników, a wśród nich 50\% stanowiłyby osoby niepełnosprawne, nadal nie kwalifikowałby się do zwolnienia z podatku VAT. Ponadto warunki kwalifikujące się do zwolnienia z podatku CIT mają również zastosowanie do zwolnienia z podatku VAT ${ }^{28}$.

Wszystkie organizacje, które zatrudniają pracowników w Chinach, są zobowiązane do podjęcia działań w celu zmniejszenia niepełnego zatrudnienia osób niepełnosprawnych. Rząd chiński ustalił minimalny limit pracowników niepełnosprawnych, których firma musi zatrudnić. Chiński plan przewiduje, że co najmniej 1,5\% pracowników w firmie to osoby niepełnosprawne. Kontyngent nie dotyczy firm obecnych na rynku poniżej 3 lat i zatrudniających mniej niż 20 pracowników.

Jeśli chiński pracodawca nie zastosuje się do tego wymogu, musi uiścić opłatę na fundusz rentowy dla osób niepełnosprawnych o nazwie Baozhang Jin. Wysokość opłaty oblicza się na podstawie łącznej liczby pracowników, a także średniej płacy lokalnej ${ }^{29}$. Choć wysokość opłaty różni się w zależności od lokalizacji firmy, to i tak większość firm decyduje się na wpłatę do funduszu zamiast zatrudnienia wymaganej liczby pracowników niepełnosprawnych. Wynika to z niechęci do ich szkolenia i włączania do struktury firmy. Fakt, że niewiele firm decyduje się na

\footnotetext{
28 D. Shira \& Associates, Hiring Disabled Workers in China: Incentives and Challenges, 2016, https:// www.chinabusinessreview.com/hiring-disabled-workers-in-china-incentives-and-challenges/ (dostęp: 3.07.2021).

29 F. Danni, Employment Quota Gives Disabled People a Hand Up to a Dead End, 2016, http://www. sixthtone.com/news/1402/employment-quota-gives-disabled-people-a-hand-up-to-a-dead-end (dostęp: 3.07.2021).
} 
skorzystanie ze zwolnienia z wpłaty na Baozhang Jin, jest jedną z głównych przyczyn niskiego wskaźnika zatrudnienia niepełnosprawnych w Chinach $^{30}$.

Pomimo wprowadzonych zasad, mających wpłynąć na korzyść zatrudnienia osób niepełnosprawnych, działania te nie rozwiązują w pełni ich problemów. Różnica między wysokością dochodów osiąganych przez osoby niepełnosprawne i pełnosprawne rośnie, a roczne statystyki ${ }^{31}$ z 2015 r. pokazują, że liczba niepełnosprawnych w Chinach, którzy znaleźli pracę w ciagu poprzedzających 3 lat, malała. Osoby niepełnosprawne uważają że ich talent i zdolność do wykonywania wykwalifikowanej, znaczącej pracy w dużej mierze nie są doceniane przez pracodawców, a wiele stanowisk oferowanych im to praca fizyczna o minimalnym wynagrodzeniu, niezapewniająca realnego potencjału dla rozwoju kariery ${ }^{32}$.

\section{Najważniejsze ulgi podatkowe i zachęty dotyczące zatrudniania osób niepełnosprawnych w Stanach Zjednoczonych}

W Stanach Zjednoczonych firmy sektora prywatnego, które wprowadzają adaptacje strukturalne lub inne udogodnienia dla pracowników lub klientów niepełnosprawnych, mogą kwalifikować się do ulg podatkowych. Istnieją również zachęty finansowe mające na celu zwiększenie zatrudnienia osób niepełnosprawnych, na poziomie zarówno federalnym, jak i stanowym ${ }^{33}$. Są one następujące:

- Work Opportunity Tax Credit (WOTC) - ulga podatkowa na zatrudnienie. Ulgi podatkowe są dostępne w ramach programu WOTC dla pracodawców zatrudniających osoby, które w przeszłości napotykały trudności w zatrudnieniu. Mogą się o nie ubiegać wszystkie firmy w związku z zatrudnianiem osób niepełnosprawnych. Ulgi te dotyczą wynagrodzeń wypłacanych pracownikowi w pierwszym roku zatrudnienia ${ }^{34}$.

- Zachęty stanowe - zgodnie z National Conference of State Legislatures wiele stanów oferuje zachęty podatkowe w zamian za zatrudnianie i szkolenie niepełnosprawnych pracowników. Na przykład w stanie Kansas prawo zezwala pracodawcy, który wydaje pieniądze na udostępnienie istniejącego obiektu dla osób niepełnosprawnych, w tym na udostępnienie sprzętu w miejscu

30 D. Shira \& Associates, Hiring Disabled Workers...

312015 年中国残疾人事业发展统计公报 [Statistical Communique on the Development of China's Disabled Persons in 2015], http://www.cdpf.org.cn/zcwj/zxwj/201604/t20160401_548 009.shtml (dostęp: 3.07.2021).

32 F. Danni, Employment Quota...

33 Employer Financial Incentives, 2020, EARN, https://askearn.org/topics/laws-regulations/employer_financial_incentives/(dostęp: 3.07.2021).

34 D. Kenney, Are There Tax Incentives for Hiring People with Disabilities?, 2021, Efficient Hire, https://www.efficienthire.com/tax-incentives-hiring-people-disabilities/ (dostęp: 3.07.2021). 
pracy, do ubiegania się o ulgę podatkową w wysokości połowy wydatków lub 10 tys. USD, w zależności od tego, co jest niższe $\mathrm{e}^{35}$.

- Disabled Access Credit - kredyt na umożliwienie dostępności niepełnosprawnym. Jest to bezzwrotny kredyt w wysokości do 5 tys. USD dla małych firm, które ponoszą wydatki w celu zapewnienia udogodnień dla osób niepełnosprawnych. Ułatwienia te to m.in. usuwanie elementów uniemożliwiających dostęp osobom niepełnosprawnym do firmy, urządzenia dla osób niepełnosprawnych, a także materiały wizualne dla osób niedowidzących ${ }^{36}$. Takie firmy mogą wziąć kredyt każdego roku, w którym ponoszą tego rodzaju wydatki ${ }^{37}$.

- Barrier Removal Tax Deduction - ulga podatkowa na usuwanie barier. Jest to możliwość odliczenia podatku od usuwania barier architektonicznych i transportowych utrudniających przemieszczanie się osobom niepełnosprawnym i osobom starszym. Firmy mogą ubiegać się o odliczenie do 15 tys. USD rocznie, wskazując je jako oddzielny koszt w zeznaniu podatkowym ${ }^{38}$.

\section{Dyskryminacja i wykluczenie społeczne}

Wiele osób z niepełnosprawnościami nie ma pełnego dostępu do opieki zdrowotnej, edukacji, równych możliwości bycia zatrudnionym, a także nie otrzymuje wymaganych świadczeń związanych z niepełnosprawnością. Takie osoby wciąż często doświadczają wykluczenia w codziennym życiu ${ }^{39}$.

W chińskim społeczeństwie nadal istnieją uprzedzenia wobec osób niepełnosprawnych, szeroko praktykowana jest dyskryminacja w życiu codziennym i miejscach pracy. Problemem jest także ogólne nieegzekwowanie prawa przez rząd. Wielu pracodawców nie zatrudnia osób niepełnosprawnych zgodnie z wymaganymi proporcjami. Biorąc pod uwagę wydatki medyczne i ubezpieczenie pracy zatrudnionych pracowników niepełnosprawnych, niektóre przedsiębiorstwa wolą opłacać fundusze zabezpieczenia zatrudnienia, niż zatrudniać osoby niepełnosprawne na stałe ${ }^{40}$. W ankiecie przeprowadzonej przez The Conference Board China Center w 2018 r. tylko

35 Ch. Leddy, The Tax Incentives for Hiring Employees with Disabilities, https://www.adp.com/ spark/articles/2018/11/the-tax-incentives-for-hiring-employees-with-disabilities.aspx (dostęp: 3.07.2021).

36 M. Reddigari, What Is Disabled Access Credit?, 2015, https://mileiq.com/blog/disabled-access-credit/ (dostęp: 3.07.2021).

37 Tax Benefits for Businesses Who Have Employees with Disabilities, IRS, https://www.irs.gov/ businesses/small-businesses-self-employed/tax-benefits-for-businesses-who-have-employees-with-disabilities (dostęp: 16.01.2020).

38 Ibidem.

39 World Health Organization \& World Bank, World report on disability 2011, Geneva 2011, s. xxi.

$40 \mathrm{~S}$. Yu, Current Situation and Problems of the Employment of Disabled Persons in China, https://www. iolaw.org.cn/showNews.aspx?id=25500 (dostęp: 3.07.2021). 
9\% firm członkowskich w Chinach stwierdziło, że w tym momencie czynnie zajmowało się problematyką związaną z niepełnosprawnością pracowników, natomiast $43 \%$ twierdziło, że kwestie dotyczące niepełnosprawności staną się dla nich ważne w przyszłości w celu zdywersyfikowania kadr pracowniczych oraz zapewnienia pomocy obecnym niepełnosprawnym pracownikom. Choć tak duża część przedsiębiorstw deklaruje zwrócenie większej uwagi na problematykę niepełnosprawności, w rzeczywistości często pozostają one tylko w sferze założeń. Aktywne działanie na rzecz likwidowania tych barier przyczyniłoby się nie tylko do zajęcia się problemem dyskryminacji praw człowieka, lecz także do poprawy wyników w zakresie zatrudnienia, a tym samym do wzrostu gospodarczego ${ }^{41}$.

Wiele dużych firm w Stanach Zjednoczonych zostało posądzonych o dyskryminację osób niepełnosprawnych. Dane dotyczące kar finansowych nakładanych z powodu dyskryminacji osób niepełnosprawnych w ciagu ostatnich 20 lat wskazuja, że większość zarzutów zostało odrzucanych z powodów administracyjnych lub braku uzasadnienia. Znaczy to, że większość osób, które wniosły oskarżenie, nie dostarczyła wystarczających dowodów potwierdzających dyskryminację lub nie spełniła odpowiednich wymogów. Na przykład w roku 2016, 2017 i 2018 odrzucono odpowiednio $80,8 \%, 82,1 \%$ i $81,6 \%$ zarzutów, a tylko $8,6 \%, 7,8 \%$ i 7,5\% wszystkich zarzutów dyskryminacji ze względu na niepełnosprawność zostało uwzględnionych, doprowadzając do zawarcia ugody ${ }^{42}$.

\section{Analiza wyników badań postrzegania firm zatrudniających osoby niepełnosprawne w Chinach i Stanach Zjednoczonych}

W lutym i marcu 2020 r. przeprowadzone zostało badanie ankietowe na grupie mieszkańców Chin, mające na celu zbadanie ich nastawienia do zatrudniania osób niepełnosprawnych. Wyniki ankiety można było następnie porównać z podobnym badaniem autorstwa G.N. Sipersteina, N. Romana, A. Mohler oraz R. Parkera, przeprowadzonym na grupie obywateli Stanów Zjednoczonych: 803 osoby (396 kobiet i 407 mężczyzn), losowo wybranych do wywiadów telefonicznych, którego celem było zbadanie postaw konsumenckich wobec zatrudniania osób niepełnosprawnych $^{43}$. Badanie w Chinach zrealizowano za pomocą metody CAWI (ang. Computer

41 S.M. Bruyere, Disability in the Workplace in China: Situation Assessment, Cornell University's ILR School, https://digitalcommons.ilr.cornell.edu/cgi/viewcontent.cgi?article=1373\&context= edicollect (dostęp: 10.12.2020).

42 Z. Crosner, Legal Guide to Disability Discrimination in the Workplace in 2019, Disability Discrimination Lawyers, https://www.crosnerlegal.com/disability-discrimination-in-the-workplace-2019/ (dostęp: 16.09.2020).

43 G.N. Siperstein, N. Romano, A. Mohler, R. Parker, A national survey of consumer attitudes towards companies that hire people with disabilities, ,Journal of Vocational Rehabilitation” 2006, vol. 24, s. 3-9. 
Assisted Web Interview) na grupie 121 osób (87 kobiet i 34 mężczyzn) w przedziale wiekowym 18-63 lat. Pytania do ankiety zostały sformułowane na podstawie danych przedstawionych w artykule opisującym wspomniane wyżej badanie amerykańskie, a następnie przetłumaczone na język chiński. Ankieta została rozpowszechniona w Chinach za pośrednictwem mediów społecznościowych. W tab. 3 przedstawiono dane demograficzne respondentów z obu badań.

Tabela 3. Charakterystyka demograficzna respondentów badania w Chinach i Stanach Zjednoczonych

\begin{tabular}{|c|c|c|c|c|c|c|}
\hline \multirow{3}{*}{ Kategoria } & \multicolumn{2}{|c|}{ Mężczyźni } & \multicolumn{2}{|c|}{ Kobiety } & \multicolumn{2}{|c|}{ Suma } \\
\hline & Chiny & $\begin{array}{c}\text { Stany } \\
\text { Zjednoczone }\end{array}$ & Chiny & $\begin{array}{c}\text { Stany } \\
\text { Zjednoczone }\end{array}$ & Chiny & $\begin{array}{c}\text { Stany } \\
\text { Zjednoczone }\end{array}$ \\
\hline & $n=34$ & $n=407$ & $n=87$ & $n=396$ & $n=121$ & $n=803$ \\
\hline \multicolumn{7}{|c|}{ Wiek (w latach) } \\
\hline $18-34$ & $82 \%$ & $28 \%$ & $95 \%$ & $27 \%$ & $92 \%$ & $27 \%$ \\
\hline $35-49$ & $15 \%$ & $32 \%$ & $3 \%$ & $30 \%$ & $7 \%$ & $31 \%$ \\
\hline $50-64$ & $3 \%$ & $27 \%$ & $2 \%$ & $25 \%$ & $1 \%$ & $26 \%$ \\
\hline Powyżej 65 & - & $12 \%$ & - & $17 \%$ & - & $15 \%$ \\
\hline \multicolumn{7}{|c|}{ Wykształcenie } \\
\hline $\begin{array}{l}\text { Liceum lub } \\
\text { niższy poziom } \\
\text { wykształcenia }\end{array}$ & $18 \%$ & $44 \%$ & $14 \%$ & $45 \%$ & $15 \%$ & $44 \%$ \\
\hline Student & $47 \%$ & $24 \%$ & $49 \%$ & $27 \%$ & $49 \%$ & $25 \%$ \\
\hline $\begin{array}{l}\text { Wykształcenie } \\
\text { wyższe }\end{array}$ & $35 \%$ & $31 \%$ & $37 \%$ & $29 \%$ & $36 \%$ & $30 \%$ \\
\hline \multicolumn{7}{|c|}{ Status zatrudnienia } \\
\hline Pełen etat & $53 \%$ & $63 \%$ & $46 \%$ & $46 \%$ & $48 \%$ & $54 \%$ \\
\hline Częściowy etat & $6 \%$ & $7 \%$ & $10 \%$ & $15 \%$ & $9 \%$ & $11 \%$ \\
\hline Niezatrudniony & $41 \%$ & $30 \%$ & $44 \%$ & $39 \%$ & $43 \%$ & $35 \%$ \\
\hline
\end{tabular}

Źródło: Opracowanie na podstawie badania własnego przeprowadzonego wśród obywateli Chin w okresie luty-marzec 2020 r. na grupie 121 osób metodą CAWI oraz badania autorstwa G.N. Sipersteina, N. Romana, A. Mohler, R. Parkera, A national survey of consumer attitudes towards companies that hire people with disabilities, ,Journal of Vocational Rehabilitation” 2006, vol. 24, s. 3-9.

$\mathrm{Na}$ podstawie przeprowadzonego badania ustalono, że w porównaniu do respondentów ze Stanów Zjednoczonych w Chinach mały odsetek osób miał bezpośrednie doświadczenie z osobami niepełnosprawnymi. Tylko 13\% badanych mieszkańców Chin zadeklarowało, że pracowali z osobą niepełnosprawną, a 25\%, że było klientem takiej osoby, przy ok. 75\% odpowiedzi amerykańskich respondentów potwierdzających te doświadczenia. Dane uzyskane w badaniu społeczności chińskiej mogą wynikać z faktu, że administracja podatkowa w Chinach nie kwalifikuje osób 
niepełnosprawnych umysłowo do osób niepełnosprawnych, tym samym firmy, nie mogąc korzystać z ulg, często nie zatrudniają lub zwalniają takich pracowników. Spośród uczestników zgłaszających doświadczenie w pracy z osobą niepełnosprawną ok. 63\% oceniła wydajność ich niepełnosprawnego współpracownika jako „bardzo satysfakcjonującą” lub „satysfakcjonującą” - wśród respondentów ze Stanów Zjednoczonych prawie wszyscy pozytywnie ocenili ten kontakt (91\%). Natomiast tylko ok. 28\% Chińczyków uznało bycie obsługiwanym przez niepełnosprawnego pracownika za „bardzo satysfakcjonujące” lub „satysfakcjonujące”. Aż 98\% Amerykanów było „,bardzo usatysfakcjonowanych” lub „usatysfakcjonowanych” z usług otrzymanych od niepełnosprawnego pracownika, zatem ocena ta była podobnie wysoka jak przy postrzeganiu wydajności pracy osób niepełnosprawnych. Omawiane dane zostały zaprezentowane w tab. 4.

Tabela 4. Doświadczenie z osobami niepełnosprawnymi

\begin{tabular}{|l|c|c|c|c|}
\hline \multicolumn{1}{|c|}{ Kategoria } & Chiny $(\boldsymbol{n})$ & $\begin{array}{c}\text { Stany } \\
\text { Zjednoczone } \\
(\boldsymbol{n})\end{array}$ & $\begin{array}{c}\text { Chiny } \\
\mathbf{( \% )}\end{array}$ & $\begin{array}{c}\text { Stany } \\
\text { Zjednoczone } \\
\mathbf{( \% )}\end{array}$ \\
\hline $\begin{array}{l}\text { Osoba niepełnosprawna jest } \\
\text { członkiem rodziny }\end{array}$ & 11 & 354 & 9 & 44 \\
\hline Praca z osobą niepełnosprawna & 16 & 565 & 13 & 70 \\
\hline $\begin{array}{l}\text { Bycie klientem osoby } \\
\text { niepełnosprawnej }\end{array}$ & 30 & 592 & 25 & 74 \\
\hline
\end{tabular}

Źródło: Opracowanie na podstawie badania własnego przeprowadzonego wśród obywateli Chin w okresie luty-marzec 2020 r. na grupie 121 osób metodą CAWI oraz badania autorstwa G.N. Sipersteina, N. Romana, A. Mohler, R. Parkera, A national survey...

W dalszej części ankiety pojawiły się pytania dotyczące postrzegania przez respondentów firm i ich działań społecznych. Jednym z celów badania było określenie, które obszary odpowiedzialności społecznej realizowane przez firmy są oceniane przez ankietowanych najbardziej pozytywnie. Sprawdzono również, w jakim stopniu zgadzaja się oni z korzyściami związanymi z zatrudnianiem osób niepełnosprawnych.

Jak wskazują dane zawarte w tab. 5, znaczna większość uczestników z obu państw pozytywnie oceniła firmy odpowiedzialne społecznie. Zarówno w Chinach, jak i w Stanach Zjednoczonych najbardziej pozytywną opinią cieszyły się firmy „oferujące ubezpieczenie zdrowotne dla wszystkich pracowników” i „pomagające przy ochronie środowiska”. Znaczącą różnica przedstawioną w tej części badania jest fakt, że „zatrudnianie osób niepełnosprawnych” w Chinach znajduje się na ostatnim miejscu spośród wszystkich działań społecznych podejmowanych przez firmy. Lącznie 70\% chińskich respondentów uważała zatrudnianie osób niepełnosprawnych za „znacznie bardziej korzystne” lub „korzystne”. W Stanach Zjednoczonych w ocenach poparcia zatrudniania osób niepełnosprawnych „włączanie 
osób niepełnosprawnych do kadr firmy” znajduje się za ,zapewnieniem ubezpieczenia zdrowotnego” i „ochroną środowiska”. Aż 92\% Amerykanów postrzega działania firm na rzecz zatrudnienia osób niepełnosprawnych jako ,znacznie bardziej korzystne” lub „korzystne”. W odniesieniu do odczuć dotyczących firm zatrudniających osoby niepełnosprawne odpowiedzi kobiet w obydwu państwach były bardziej pozytywne niż odpowiedzi mężczyzn. Generalnie oba badania w przeważającej mierze wykazały, że kobiety są bardziej pozytywnie nastawione do osób niepełnosprawnych niż mężczyźni. Być może wiąże się to z potencjalnie większą wrażliwością i empatią kobiet.

Tabela 5. Postrzeganie przez respondentów firm wykazujących się odpowiedzialnością społeczną w danym obszarze $(\%)$

\begin{tabular}{|c|c|c|c|c|c|c|c|c|c|c|}
\hline \multirow[t]{2}{*}{ Kategoria } & . & 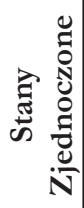 & : & 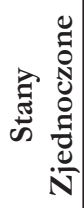 & : & 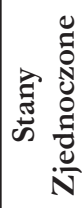 & 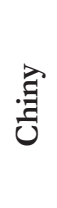 & 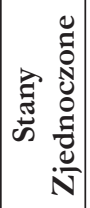 & . & 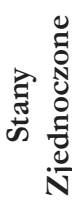 \\
\hline & \multicolumn{2}{|c|}{$\begin{array}{l}\text { znacznie } \\
\text { bardziej } \\
\text { korzystne }\end{array}$} & \multicolumn{2}{|c|}{$\begin{array}{l}\text { bardziej } \\
\text { korzystne }\end{array}$} & \multicolumn{2}{|c|}{ takie samo } & \multicolumn{2}{|c|}{$\begin{array}{c}\text { mniej } \\
\text { korzystne }\end{array}$} & \multicolumn{2}{|c|}{$\begin{array}{l}\text { znacznie } \\
\text { mniej } \\
\text { korzystne }\end{array}$} \\
\hline $\begin{array}{l}\text { Oferowanie ubezpieczenia } \\
\text { zdrowotnego wszystkim } \\
\text { pracownikom }\end{array}$ & 76 & 46 & 13 & 48 & 7 & 3 & 2 & 1 & 2 & $<1$ \\
\hline $\begin{array}{l}\text { Pomaganie w ochronie } \\
\text { środowiska }\end{array}$ & 68 & 36 & 17 & 56 & 11 & 6 & 2 & 2 & 2 & 0 \\
\hline $\begin{array}{l}\text { Zatrudnianie osób } \\
\text { niepełnosprawnych }\end{array}$ & 41 & 32 & 29 & 60 & 27 & 5 & 2 & 1 & 1 & 1 \\
\hline $\begin{array}{l}\text { Przekazywanie pieniędzy } \\
\text { na pomoc w wypadku } \\
\text { katastrof }\end{array}$ & 53 & 31 & 23 & 56 & 19 & 7 & 3 & 4 & 2 & 1 \\
\hline $\begin{array}{l}\text { Wspieranie sprawy, na } \\
\text { której danej osobie zależy }\end{array}$ & 49 & 29 & 28 & 60 & 18 & 9 & 2 & 2 & 2 & $<1$ \\
\hline
\end{tabular}

Źródło: Opracowanie na podstawie badania własnego przeprowadzonego wśród obywateli Chin w okresie luty-marzec 2020 r. na grupie 121 osób metodą CAWI oraz badania autorstwa G.N. Sipersteina, N. Romana, A. Mohler, R. Parkera, A national survey..., s. 3-9.

W tab. 6 przedstawiono postrzeganie korzyści wynikających z zatrudniania osób niepełnosprawnych. Znaczna większość respondentów, zarówno w Chinach, jak i w Stanach Zjednoczonych, pozytywnie ocenia wartości i korzyści związane z zatrudnianiem osób niepełnosprawnych. Aż 83\% badanych w Chinach i 96\% w Stanach Zjednoczonych uważa, że zatrudnienie niepełnosprawnego odgrywa dużą rolę w prowadzeniu bardziej produktywnego życia. Ankietowani zgadzają się, że zatrudnienie 
Tabela 6. Postrzeganie przez ankietowanych prawdopodobnych korzyści i problemów wynikających z zatrudnienia osób niepełnosprawnych zarówno dla firm, jak i osób niepełnosprawnych $(\%)$

\begin{tabular}{|c|c|c|c|c|c|c|c|c|c|c|}
\hline \multirow[t]{2}{*}{ Kategoria } & 胥 & 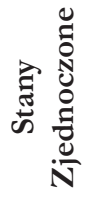 & : & 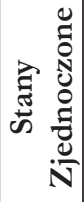 & : & 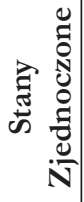 & 尔 & 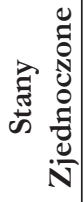 & 胥 & 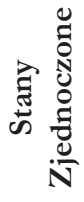 \\
\hline & \multicolumn{2}{|c|}{$\begin{array}{l}\text { zdecydowanie } \\
\text { się zgadzam }\end{array}$} & \multicolumn{2}{|c|}{$\begin{array}{l}\text { zgadzam } \\
\text { się }\end{array}$} & \multicolumn{2}{|c|}{ neutralny } & \multicolumn{2}{|c|}{$\begin{array}{c}\text { nie } \\
\text { zgadzam } \\
\text { się }\end{array}$} & \multicolumn{2}{|c|}{$\begin{array}{l}\text { zdecydowanie } \\
\text { się nie } \\
\text { zgadzam }\end{array}$} \\
\hline $\begin{array}{l}\text { Umożliwienie osobom } \\
\text { niepełnosprawnym } \\
\text { prowadzenia bardziej } \\
\text { produktywnego życia }\end{array}$ & 60 & 47 & 23 & 49 & 13 & 1 & 2 & 3 & 2 & $<1$ \\
\hline $\begin{array}{l}\text { Pomoc innym } \\
\text { współpracownikom } \\
\text { w lepszym } \\
\text { zrozumieniu osób } \\
\text { niepełnosprawnych }\end{array}$ & 43 & 40 & 23 & 50 & 24 & 3 & 8 & 5 & 2 & 1 \\
\hline $\begin{array}{l}\text { Pokazanie swoim } \\
\text { klientom, że wszyscy } \\
\text { pracownicy są brani } \\
\text { pod uwagę }\end{array}$ & 34 & 40 & 26 & 53 & 31 & 3 & 6 & 4 & 3 & 1 \\
\hline $\begin{array}{l}\text { Są to firmy, którym } \\
\text { moglibyśmy powierzyć } \\
\text { swoją działalność }\end{array}$ & 22 & 33 & 18 & 54 & 44 & 6 & 7 & 4 & 9 & 1 \\
\hline $\begin{array}{l}\text { Częste } \\
\text { wykorzystywanie } \\
\text { pracowników } \\
\text { z niepełnosprawnością }\end{array}$ & 2 & 5 & 2 & 14 & 14 & 4 & 15 & 51 & 67 & 22 \\
\hline $\begin{array}{l}\text { Osoby } \\
\text { niepełnosprawne } \\
\text { stwarzają problemy } \\
\text { w środowisku pracy }\end{array}$ & 4 & 2 & 3 & 12 & 27 & 3 & 23 & 60 & 43 & 20 \\
\hline
\end{tabular}

Źródło: Opracowanie na podstawie badania własnego przeprowadzonego wśród obywateli Chin w okresie luty-marzec 2020 r. na grupie 121 osób metodą CAWI oraz badania autorstwa G.N. Sipersteina, N. Romana, A. Mohler, R. Parkera, A national survey..., s. 3-9.

jest ważne dla osoby niepełnosprawnej. Znacznie mniej entuzjastycznie oceniono w Chinach „powierzanie swojej działalności osobie niepełnosprawnej” (w sensie zlecenia ważnego procesu w firmie): tylko $40 \%$ osób „zdecydowanie się zgodziło” 
lub „zgodziło się”. Natomiast w Stanach osoby aprobujące ten fakt stanowią 87\% wszystkich ankietowanych. Z kolei pogląd wskazujący, że „osoby niepełnosprawne stwarzaja problemy w miejscu pracy” czy że ma miejsce „częste wykorzystywanie takich pracowników przez firmy”, został zanegowany przez większość respondentów z obydwu państw.

Tabela 7. Wpływ doświadczenia z osobami niepełnosprawnymi na ich postrzeganie przez chińskich respondentów (\%)

\begin{tabular}{|c|c|c|c|c|}
\hline Kategoria & 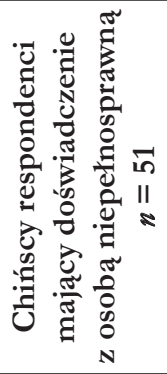 & 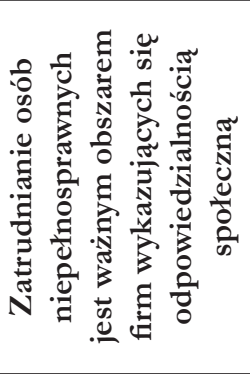 & 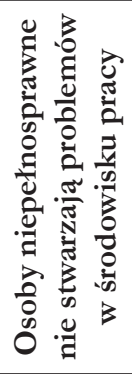 & 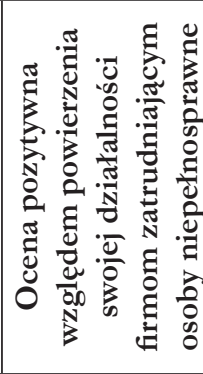 \\
\hline $\begin{array}{l}\text { Respondenci, którzy } \\
\text { mają w rodzinie } \\
\text { niepełnosprawną osobę }\end{array}$ & 22 & 90 & 100 & 73 \\
\hline $\begin{array}{l}\text { Respondenci, którzy } \\
\text { pracowali z osobą } \\
\text { niepełnosprawną }\end{array}$ & 31 & 93 & 93 & 81 \\
\hline $\begin{array}{l}\text { Respondenci, którzy } \\
\text { byli klientami osoby } \\
\text { niepełnosprawnej }\end{array}$ & 59 & 57 & 93 & 80 \\
\hline
\end{tabular}

Źródło: Opracowanie na podstawie badania własnego przeprowadzonego wśród obywateli Chin w okresie luty-marzec 2020 r. na grupie 121 osób metodą CAWI.

Kolejna część badań została poświęcona sprawdzeniu, czy w Chinach posiadanie doświadczenia z osobą niepełnosprawną ma wpływ na postrzeganie tej osoby. Jest to bardzo istotna kwestia, ponieważ osoby niepełnosprawne borykaja się z licznymi uprzedzeniami, stygmatyzacja, zarówno w miejscu pracy, jak i w życiu codziennym. Określenie, czy własne doświadczenie może zmienić postrzeganie osób niepełnosprawnych na ich korzyść, pokazuje, jak tak naprawdę oceniane są te osoby. Z odpowiedzi zaprezentowanych w tab. 7 wynika, że kontakt z osobami niepełnosprawnymi wiąze się pozytywną oceną zarówno wydajności, jak i funkcjonowania osób niepełnosprawnych w środowisku pracy. Doświadczenie z osobą niepełnosprawną miało ok. 42\% respondentów z Chin. Spośród osób, które pracowały z niepełnosprawnym bądź były klientem takiej osoby, ponad połowę ankietowanych satysfakcjonowało takie doświadczenie. Ponadto aż 95\% stwierdza, że osoby niepełnosprawne nie sprawiają problemów w miejscu pracy, a $78 \%$ z nich 
chętnie powierzyłoby swoją działalność takim osobom. Z kolei 80\% respondentów z Chin mających kontakt z niepełnosprawnymi uważa ich zatrudnianie za istotna działalność firm na rzecz realizowania idei odpowiedzialności społecznej. W amerykańskim badaniu odpowiedzi respondentów były podobne. Większość ankietowanych $(75 \%)$ miała bezpośredni kontakt z osobami niepełnosprawnymi, a swoje doświadczenie z nimi oceniała jako pozytywne.

Wśród ankietowanych osób w Chinach znaczna większość zareagowała pozytywnie na firmy wykazujące odpowiedzialność społeczną we wszystkich kategoriach, w tym na firmy zatrudniające osoby niepełnosprawne.

Wyniki amerykańskiego badania pokazują, że respondenci, bez względu na wiek i wykształcenie, postrzegają firmy zatrudniające osoby niepełnosprawne równie korzystnie jak firmy zapewniające ubezpieczenie zdrowotne wszystkim pracownikom oraz firmy aktywnie chroniące środowisko. Pozwala to stwierdzić, że przedsiębiorstwa powinny być bardziej świadome tego, iż zatrudnianie osób niepełnosprawnych należy do kategorii społecznej odpowiedzialności i jest ważnym czynnikiem wpływającym na wizerunek firmy. Opinia publiczna w obydwu krajach mocno wierzy, że zatrudniający osoby niepełnosprawne pomagają im prowadzić bardziej produktywne życie, umożliwiają lepsze zrozumienie niepełnosprawnych pracowników, a jednocześnie pokazują klientom, iż dbają o wszystkich pracowników.

\section{Podsumowanie}

Analiza różnic występujących między wynikami obu omawianych badań zobrazowała postrzeganie zatrudniania osób niepełnosprawnych przez społeczeństwo chińskie oraz społeczeństwo amerykańskie, co było celem niniejszego artykułu. Liczba i dobór uczestników z obydwu krajów moga mieć wpływ na otrzymane wyniki, dlatego badanie to trzeba traktować jako pilotażowe. Niemniej jednak ujawnia ono potrzebę prowadzenia dalszych analiz tego tematu i wskazuje na możliwe problemy, jakich doświadczają osoby niepełnosprawne w Chinach.

Choć mogłoby się wydawać, że odpowiedzi respondentów będą jednoznacznie wskazywać na pozytywne odczucia związane z doświadczeniami z osobami niepełnosprawnymi czy korzyści zatrudniania takich osób, to zarówno w Chinach, jak i w Stanach Zjednoczonych pojawiły się także opinie negatywne, co wskazuje na istniejący problem. Ogólnie bardziej negatywne opinie wyrażone zostały przez chińskich obywateli w porównaniu do obywateli amerykańskich. Najbardziej widoczne różnice pojawiły się przy ocenie wydajności pracy osoby niepełnosprawnej, jak również przy ocenie doświadczenia bycia obsługiwanym przez taką osobę. Doświadczenie obywateli Stanów Zjednoczonych było znacznie bardziej pozytywne, 98\% usatysfakcjonowanych ze świadczonych usług respondentów ze Stanów Zjednoczonych do tylko ok. 28\% zadowolonych ankietowanych z Chin. Jednak reakcja 
na stwierdzenie, że „osoby niepełnosprawne stwarzaja problemy w miejscu pracy” spotkała się z większym poparciem u amerykańskich obywateli (14\%), w porównaniu do 7\% Chińczyków.

$\mathrm{Na}$ podstawie przeprowadzonych badań można wskazać pewne postawy wobec osób niepełnosprawnych, występujące niezależnie od kraju pochodzenia respondentów. Mianowicie kobiety pozytywniej niż mężczyźni postrzegają osoby niepełnosprawne i ich funkcjonowanie w społeczeństwie. Ponadto osoby mające wcześniejsze doświadczenia z niepełnosprawnymi są nastawione do nich bardziej przychylnie. Stąd nasuwa się wniosek, że ludzie generalnie obawiają się nieznanych zjawisk, które przez wieki ulegały stygmatyzacji. Tak również dzieje się z niepełnosprawnością.

Podsumowując wyniki przeprowadzonego porównania, hipoteza H1, dotycząca podobieństwa w nastawieniu do zatrudniania niepełnosprawnych, zarówno w Chinach, jak i Stanach Zjednoczonych została zweryfikowana negatywnie.

Hipoteza H2, która dotyczyła korzyści wynikających z włączania osób niepełnosprawnych do kadr firmy, została potwierdzona. Biorąc pod uwage wszystkich respondentów, bez względu na ich doświadczenie z osobami niepełnosprawnymi, społeczeństwo chińskie darzy mniejszym zaufaniem osoby niepełnosprawne niż Amerykanie, jednak mieszkańcy obu krajów potwierdzają, że zatrudnienie odgrywa istotną rolę w życiu osób z niepełnosprawnościami.

Hipoteza H3 została zweryfikowana pozytywnie - posiadanie doświadczenia z niepełnosprawnymi ma znaczący wpływ na ocenę pracy, a także okazywanie przychylności takim osobom (na ich korzyść). Wyniki badania dotyczące tego zagadnienia obrazują zakorzenione ludzkie obawy oraz pochopnie formułowane opinie, które podczas weryfikacji okazują się zupełnie bezpodstawne.

\section{Literatura}

Ada National Network, What is the definition of disability under the ADA?, 2019, https://adata.org/ faq/what-definition-disability-under-ada (dostęp: 3.07.2021).

Barnes C., Mercer G., Niepetnosprawność, tłum. P. Morawski, Warszawa 2008.

Bruyere S.M., Disability in the Workplace in China: Situation Assessment, Cornell University's ILR School, https://digitalcommons.ilr.cornell.edu/cgi/viewcontent.cgi?article=1373\&context= edicollect (dostęp: 10.12.2020).

China Disabled Person's Federation, Law on the Protection of Persons with Disabilities, http:// www.cdpf.org.cn/english/Resources/lawsregulations/201603/t20160303_542879.shtml (dostęp: 3.05.2020).

China: End Discrimination, Exclusion of Children With Disabilities, Human Rights Watch, 2013, https://www.hrw.org/news/2013/07/15/china-end-discrimination-exclusion-children-disabilities (dostęp: 3.07.2021).

Crosner Z., Legal Guide to Disability Discrimination in the Workplace in 2019, Disability Discrimination Lawyers, https://www.crosnerlegal.com/disability-discrimination-in-the-workplace-2019/ (dostęp: 16.09.2020). 
Danni F., Employment Quota Gives Disabled People a Hand Up to a Dead End, 2016, http://www. sixthtone.com/news/1402/employment-quota-gives-disabled-people-a-hand-up-to-a-deadend (dostęp: 3.07.2021).

Davis F., Deviance disavowal: The management of strained interaction the visibly handicapped, „Social Problems" 1961, vol. 9, no. 2.

Disability: IN. Global Directory, China, 2019, https://private.disabilityin.org/global/china/ (dostęp: 3.07.2021).

Employer Financial Incentives, 2020, EARN, https://askearn.org/topics/laws-regulations/employer_financial_incentives/(dostęp: 3.07.2021).

Facts on People with Disabilities in China. International Labour Organization, https://www.ilo. org/wcmsp5/groups/public/---asia/ (dostęp: 14.09.2020).

Greater Manchester Coalition of Disabled People, Young Disabled People's Group, 1996, Resource Sheet I.

Hebl M., Kleck R., Społeczne konsekwencje niepetnosprawności fisycznej [w:] Społeczna psychologia pietna, red. T. Heatherton, R. Kleck, M. Hebl, J.G. Hull, tłum. J. Radzicki i in., Warszawa 2008.

Hernandez B., Keys C., Balcazar F., Employer attitudes toward workers with disabilities and their ADA employment rights: A literature review, „Journal of Rehabilitation” 2000, vol. 66, issue 4.

Hernandez V., Making Good on the Promise of International Law: The Convention on the Rights of Persons with Disabilities and Inclusive Education in China and India, Pacific Rim Law \& Policy, „Journal Association" 2008, vol. 17.

Kenney D., Are There Tax Incentives for Hiring People with Disabilities?, 2021, Efficient Hire, https:// www.efficienthire.com/tax-incentives-hiring-people-disabilities/ (dostęp: 3.07.2021).

Kritzer J., Special Education in China, „Eastern Education Journal” 2011, vol. 40, no. 1.

Leddy Ch., The Tax Incentives for Hiring Employees With Disabilities, https://www.adp.com/spark/articles/2018/11/the-tax-incentives-for-hiring-employees-with-disabilities.aspx (dostęp: 3.07.2021).

Ledman R., Brown D., The American with Disabilities Act: The Cutting Edge to Managing Disability, „Sam Advanced Management Journal” 1993, vol. 58.

Liu J., Ma H., Mental health system in China: history, recent service reform and future challenges, „World Psychiatry" 2011, vol. 10, no. 3.

Mergenhagen P., Enabling Disabled Workers, „American Demographics” 1997, vol. 19, no. 7.

Reddigari M., What Is Disabled Access Credit?, 2015, https://mileiq.com/blog/disabled-access-credit/ (dostęp: 3.07.2021).

Shaoxiang Yu, Current Situation and Problems of the Employment of Disabled Persons in China, https:// www.iolaw.org.cn/showNews.aspx?id=25500 (dostęp: 3.07.2021).

Shira D. \& Associates, Hiring Disabled Workers in China: Incentives and Challenges, 2016, https://www. chinabusinessreview.com/hiring-disabled-workers-in-china-incentives-and-challenges/2016 (dostęp: 3.07.2021).

Siordia C., Proxy-reports in the Ascertainment of Disability Prevalence with American Community Survey Data, ,Journal Frailty \& Aging” 2014, vol. 3, no. 4.

Siperstein G.N., Romano N., Mohler A., Parker R., A national survey of consumer attitudes towards companies that hire people with disabilities, ,Journal of Vocational Rehabilitation” 2006, vol. 24.

Social Security Administration, Disability Benefits, No. 05-10029, [b.m.] 2021.

Tax Benefits for Businesses Who Have Employees with Disabilities, IRS, https://www.irs.gov/ businesses/small-businesses-self-employed/tax-benefits-for-businesses-who-have-employees-with-disabilities (dostęp: 16.01.2020).

Unger D.D., Employers' attitudes toward persons with disabilities in the workeforce: myths or realities?, „Focus on Autism and Other Developmental Disabilities" 2002, vol. 17, issue 1. 
US Census Bureau, Census Brief. Disabilities Affect One-Fifth of All Americans, Washington, DC 1997. CENBR/97-5

Wilmowska-Pietruszyńska A., Niepetnosprawność, „Orzecznictwo Lekarskie” 2009, nr 6(2).

Wolińska J., Percepcja spokeczna, stereotyp niepetnosprawności - perspektywa aktora i obserwatora, „Annales Universitatis Mariae Curie-Skłodowska. Sectio J, Paedagogia-Psychologia” 2015, vol. 28.

World Health Organization \& World Bank, World report on disability 2011. World Health Organization, Geneva 2011.

中国政府主要职能 [Main Functions of the China Disabled Persons' Federation, China Disabled Persons' Federation], http://www.cdpf.org.cn/english/About/overview_1793/ (dostęp: 3.07.2021).

中国残疾人联合会 [Regulations on the Employment of Persons with Disabilities], http:// www.cdpf.org.cn/english/Resources/lawsregulations/201603/t20160303_542878.shtml (dostęp: 3.03.2020).

2015 年中国残疾人事业发展统计公报 [Statistical Communique on the Development of China's Disabled Persons in 2015], http://www.cdpf.org.cn/zcwj/zxwj/201604/t20160401_548009. shtml (dostęp: 3.07.2021).

\section{SUMMARY}

\section{THE PERCEPTION OF EMPLOYING PEOPLE WITH DISABILITIES IN CHINA AND THE UNITED STATES}

The concept of disability has been accompanied by controversies, stereotypes and stigmatization for years. Despite the fact that the number of people with disabilities in China and the United States is still growing, the issue of perceiving the functioning of disabled people in the society and including them to the work environment remains unsolved, notwithstanding the number of legal regulations and financial incentives in China and USA to change the employment of people with disabilities. This study compares the perception of employment of people with disabilities in China and the United States. The comparison was based on a self-conducted study among the Chinese community between February and March 2020 on a group of 121 people using the CAWI method (Computer Assisted Web Interview) and an American study: $A$ national survey of consumer attitudes towards companies that hire people with disabilities, by G.N. Siperstein, N. Romano, A. Mohler, and R. Parker, conducted on 803 residents of the USA randomly selected for telephone interviews. The comparison took place, among others, in the assessment of the employment of disabled people by respondents in the context of other social activities in the company, as well as the satisfaction of the respondents with the results of the disabled at work. It was pointed out that in both China and the USA, previous experiences with people with disabilities may affect a more favorable approach towards employing disabled people. However, there are differences in the satisfaction with services provided by people with disabilities, as well as in trust in disabled workers, where Chinese residents have less positive attitude than their American counterparts. 